\title{
PENGARUH PEMBERIAN EKSTRAK BAYAM MERAH TERHADAP PENINGKATAN KADAR HB PADA IBU HAMIL DI KLINIK VINA MEDAN
}

\author{
Adriana Bangun ${ }^{1}$, Faija Sihombing ${ }^{2}$ \\ 1,2 Fakultas Kesehatan,Universitas Audi Indonesia, Indonesia \\ adrianabangun1988@gmail.com,faija_sihombing22@gmail.com
}

\begin{abstract}
Nutritional anemia is a condition when blood hemoglobin levels are lower than normal because of the inability of constituents of red blood cells in production to maintain hemoglobin level nationally. Red spinach is often found in traditional markets in Medan. But, there are so many pregnant mothers who do not know that red spinach could increase hemoglobin level for them, so during this time, red spinach is still used by them for being used as vegetables only. This research aims to help pregnant mothers getting food sources rich in zinc. It's easy and affordable in their environment. So, there is no more pregnant mother has anemia and it can decrease maternal mortality rate of bleeding during birth. The design of this research uses One Group Pre Post Test experiment. It is through looking at the improvement of mothers' hemoglobin level before and after consuming red spinach extract. The sampling is done by a total sampling technique which is 30 pregnant mothers. The analysis with the statistic test, t independent test in confidence level $95 \%$. The result of research shows that the mean of hemoglobin level before giving red spinach extract is $13.7 \mathrm{~g} / \mathrm{dL}$ (minimal $=8,7 \mathrm{~g} / \mathrm{dL}$ and maximal $=$ $13,7 \mathrm{~g} / \mathrm{dL}$ ), the mean of hemoglobin level after giving red spinach extract is $12,4 \mathrm{~g} / \mathrm{dL}$ (minimal $=8,1 \mathrm{~g} / \mathrm{dL}$ and maximal $=16,0 \mathrm{~g} / \mathrm{dL}$ ). The difference of before and after giving red spinach extract is around 28 people $(93,3 \%)$ and there is an influence in giving red spinach extract for increasing the blood hemoglobin level of pregnant mothers in Klinik Vina Medan.
\end{abstract}

Keyword: Extract, Red spinach, pregnant mother, increase of Hemoglobin, Anemia.

\section{PENDAHULUAN}

Kehamilan merupakan harapan dari setiap wanita yang sudah memiliki pernikahan. Akan tetapi masih banyak kehamilan yang disertai dengan anemia, sehingga dapat menyebabkan perdarahan ketika proses persalinan, dan hal ini akan menyokong tingginya angka kematian Ibu ((R. Y. Astuti \& Ertiana, 2018).

Menurut Data dari direktorat kesehatan keluarga $40 \%$ penyebab kematian adalah perdarahan dan diketahui bahwa anemia adalah penyebab perdarahan. Pemberian tablet Fe masih belum mencapai target sesuai standart yang telah ditentukan yaitu cakupan pemberian tablet $\mathrm{Fe} 3$ selama kehamian sebesar $90 \%$. Manfaat tablet Fe sangat besar terhadap pencegahan anemia pada ibu hamil. Namun masih banyak ibu hamil yang tidak mengkonsumsi tablet $\mathrm{Fe}$ sampai 90 tablet. Hasil Riskesdas tahun 2013 dari $89,1 \%$ ibu hamil yang mengkonsumsi tablet $\mathrm{Fe}$ hanya $33.3 \%$ yang mengkonsumsi sampai 90 tablet $\mathrm{Fe}$ 
sesuai anjuran Sampai saat ini belum dapat mencapai hasil yang maksimal, terbukti dari prevalensi anemia pada Ibu hamil yang masih tinggi, berdasarkan data laporan Profil Kesehatan Indonesia tahun 2014, rata-rata cakupan pemberian tablet Fe-3 Nasional adalah $85.1 \%$ dan rata-rata cakupan pemberian tablet $\mathrm{Fe}-3$ di Provinsi Sumatra Utara pada tahun 2017 masih di bawah rata-rata Nasional yaitu sebesar $87.4 \%$ dengan target RPJMN sebanyak 90\% Hal ini berarti masih ada kesenjangan sebesar 2.9\% (Kemenkes, 2018)

Berdasarkan data Seksi Gizi Dinkes Kota Medan tahun 2019, ratarata cakupan pemberian tablet $\mathrm{Fe}-3$ kurang dari target yaitu $90.4 \%$ dengan target RPJMN sebanyak 100\% (Dinkes Medan, 2019)

\section{Menurut World Health} Organization (WHO) (2016), prevalensi anemia di dunia antara berkisar 40 88\%. Berdasarkan hasil Riset Kesehatan Dasar (Riskesdas) tahun 2018, prevalensi anemia pada ibu hamil di Indonesia sebesar 37,1 \%. Data dari Dinas Kesehatan Provinsi Sumatra Utarapada tahun 2016 angka kejadian anemia pada ibu hamil sebesar $24 \%$ dan Di Kota Medan angka anmeia mecapai $46 \%$, dari beberapa kecamatan yang ada di kota medan, kecamata Medan Baru memiliki angka anemia sebanyak $25 \%$ dengan kadar $\mathrm{Hb}$ 8-11 mg/dl (Dinkes Medan, 2019)

Kota medan merupakan ibu kota provinsi Sumatra Utara yang sangat cepat mendapat dan merespon segala informasi terbaru yang ada. Akan tetapi dalam hal bayam merah, mendapat sedikit perbedaan, karena masih banyak ibu hamil yang mengatakan tidak mengetahui bahwa bayam merah dapat meningkatkan kadar HB pada ibu hamil (Dinkes Medan, 2019)

Bayam merah atau (amaranthus tricolor L) merupakan salah satu tanaman yang sangat mudah ditemukan dipasar tradisional bahkan di mol mol ternama. Akan tetapi sejauh ini mindseet ibu ibu atau masyarakat tentang bayam merah masih sejauh kegunaan sebagai sayuran. Bayam merah merupakan salah satu sayuran yang sangat mudah untuk dibudidayakan, dan bayam merah juga sangat cocok hidup d hawa panas seperti kota Medan. Dipekarangan rumah juga bisa dibudiayakan dengan menggunakan pot. Masih banyak masyrakat yang belum mengetahui manfaat bayam merah. Berdasarkan penelitian Pradana bahwa ekstrak etanolik daun bayam merah terstandar berpotensi sebagai terapi preventif perlemakan hati (Pradana et al., 2017).

$\begin{array}{ccc}\text { Berdasarkan penelitian } & \text { yang } \\ \text { dilakukan oleh } & \text { lathifah, } & 2019 \\ \text { mengatakan bahwa } & \text { Jus bayam } & \text { merah }\end{array}$


jika di konsumsi dengan baik dan teratur juga dapat meningkatkan kadar HB ibu hamil (Lathifah \& Susilawati, 2019)

Survey pendahuluan pada bulan maret 2019 kepada 5 orang ibu hamil di Klinik Vina J1 Jamin Ginting Kota Medan mereka mengatakan bahwa 3 ibu tidak menyukai bayam merah dan tidak tahu bahwa bayam merah tersebut dapat meningkatkan kadar HB pada ibu dan yang dua lagi mengatakan bahwa tidak suka dengan bayam merah.

Berdasarkan latar belakang diatas maka penulis tertarik ingin melakukan penelitian dengan judul pengaruh pemberian ekstrak bayam merah terhadap peningkatan kadar hb pada ibu hamil Di Klinik Vina Medan.

Penelitian ini bertujuan untuk melihat pengaruh pemberian ekstrak bayam merah terhadap kadar HB ibu hamil di Klinik Vina Kota Medan Tahun 2020.

METODE

Tabel 1. Rata-Rata Kadar Hemoglobin Sebelum Pemberian Ekstrak Bayam Merah pada ibu hamil di klinik vina Medan

\begin{tabular}{clccc}
\hline No & \multicolumn{1}{c}{ Kadar } & Maximum & Mean \\
\hline 1 & Hemoglobin & Minimum & 13,7 & 11.955 \\
& $\begin{array}{l}\text { Kadar } \\
\text { Hemoglobin } \\
\text { Sebelum }\end{array}$ & 8,7 & & \\
\hline
\end{tabular}


Tabel 2. Rata-Rata Kadar Hemoglobin Sesudah Pemberian Ekstrak Bayam Merah pada ibu hamil di klinik vina Medan

\begin{tabular}{clcccc}
\hline No & \multicolumn{2}{c}{ Kadar Hemoglobin } & Minimum & Maximum & Mean \\
\hline 1 & $\begin{array}{l}\text { Kadar } \\
\text { Sesudah }\end{array}$ & Hemoglobin & 8,1 & 16,0 & 12.404 \\
\hline
\end{tabular}

Tabel 3. Perbedaan Kadar Hemoglobin Sebelum dan Sesudah Pemberian Ekstrak Bayam Merah

\begin{tabular}{|c|c|c|c|c|c|c|c|c|c|}
\hline \multirow{3}{*}{ Hemoglobin } & \multirow{2}{*}{\multicolumn{2}{|c|}{ Non Anemia }} & \multicolumn{6}{|c|}{ Anemia } & \multirow{3}{*}{$P$ value } \\
\hline & & & \multicolumn{2}{|c|}{ Ringan } & \multicolumn{2}{|c|}{ Sedang } & \multicolumn{2}{|c|}{ Berat } & \\
\hline & $\mathrm{f}$ & $\%$ & $f$ & $\%$ & $\mathrm{f}$ & $\%$ & $f$ & $\%$ & \\
\hline Sebelum & 18 & 58,3 & 5 & 19,0 & 7 & 22,5 & 0 & 0 & \\
\hline Sesudah & 14 & 57,1 & 11 & 29,8 & 5 & 13,1 & 0 & 0 & 0,002 \\
\hline Total & 100 & 57,7 & 13 & 24,4 & 12 & 17,9 & 0 & 0 & \\
\hline
\end{tabular}

1. Kadar Hemoglobin pada ibu hamil di klinik vina Medan

Hasil penelitian diperoleh bahwa rata-rata kadar hemoglobin sebelum pemberian ekstrak bayam merah pada ibu hamil di klinik vina Medan sebesar $11.955 \mathrm{~g} / \mathrm{dL}$ dengan kadar hemoglobin minimum 8,7 g/dL dan maksimum 13,7 $\mathrm{g} / \mathrm{dL}$ dan setelah pemberian ekstrak bayam merah pada ibu hamil di klinik vina Medan sebesar $12.404 \mathrm{~g} / \mathrm{dL}$ dengan kadar hemoglobin minimum 8,1 $\mathrm{g} / \mathrm{dL}$ dan maksimum 16,0 g/dL. Keadaan ini menunjukkan bahwa kadar hemoglobin pada ibu hamil di klinik vina Medan sebelum dan sesudah pemberian ekstrak bayam merah terdapat ada yang mengalami anemia sedang. Tetapi setelah pemberian ekstrak bayam merak rata-rata kadar hemoglobin pada ibu hamil di klinik vina Medan mengalami peningkatan.
(R. Y. Astuti \& Ertiana, 2018) tentang pengaruh konsumsi jus bayam merah terhadap peningkatan kadar $\mathrm{Hb}$ pada ibu hamil di Kecamatan Tawangmangu diperoleh bahwa nilai rata-rata kadar kemoglobin mengalami peningkatan setelah pemberian jus bayam merah yaitu nilai rata-rata (mean) kadar $\mathrm{Hb}$ sebelum perlakuan yaitu 11,210 gr\%, nilai rata-rata kadar $\mathrm{Hb}$ sesudah perlakuan pada minggu I yaitu 11,850 gr\% dan nilai rata-rata (mean) sesudah perlakuan minggu II yaitu $12,140 \mathrm{gr} \%$. Nilai rata-rata (mean) kenaikan kadar $\mathrm{Hb}$ selama 2 minggu perlakuan yaitu $0,93 \mathrm{gr} \%$.

Keadaan kadar hemoglobin setelah pemberian ekstrak bayam merah ada yang mengalami penurunan kadar hemoglobin, hal ini terjadi bukan karena setelah mengkonsumsi ekstrak bayam merah mengakibatkan penurunan kadar hemoglobin tetapi mungkin karena 
kebetulan saja atau ada faktor lain yang mengakibatkan penurunan kadar hemoglobin misalnya pemberian ekstrak bayam merah tidak mampu menaikkan kadar hemoglobin karena konsumsi asupan gizi yang kurang dari ibu hamil.

\section{Pengaruh Pemberian Ekstrak Bayam Merah Terhadap Peningkatan Kadar Hemoglobin Pada pada ibu hamil}

Hasil penelitian diperoleh bahwa kadar hemoglobin sebelum dan sesuah pemberian ekstrak bayam merah pada ibu hamil di klinik vina Medan mengalami kenaikan kadar hemoglobin sebanyak 28 orang $(93.3 \%)$ dan mengalami penurunan kadar hemoglobin sebanyak 2 orang $(6,7 \%)$. Kemudian hasil uji statistik T-tes didapatkan nilai $\mathrm{p}$ $=0.002<\alpha=0,05$, berarti Ho ditolak artinya terdapat pengaruh pemberian ekstrak bayam merah terhadap peningkatan kadar hemoglobin pada ibu hamil.

Keadaan ini menunjukkan bahwa kadar hemoglobin pada ibu hamil di klinik vina Medan setelah pemberian ekstrak bayam merahsignifikan menaikkan kadar hemoglobin, dapat dilihat bahwa pada ibu hamil di klinik vina Medan ada mengalami penaikan kadar hemoglobin mencapai 93.3\%. Keadaan ini berarti bahwa ada pengaruh pada ibu hamil di klinik vina Medan dengan pemberian ekstrak bayam merah.
Bayam merah memiliki manfaat baik bagi tubuh karena merupakan sumber kalsium, kandungan vitamin pada bayam adalah vitamin A, B2, B6, $\mathrm{B} 12, \mathrm{C}, \mathrm{K}$, mangan, magnesium, zat besi, kalsium, kalium, fosfor, serat dan juga betakaroten. Selain itu, bayam juga memiliki kandungan zat besi yang tinggi untuk mencegah anemia, kandungan mineral dalam bayam cukup tinggi, terutama Fe yang dapat digunakan untuk mencegah kelelahan akibat anemia (Dieny, 2014)

Bayam merah mudah diolah menjadi berbagai macam makanan atau ekstrak herbal yang lebih variatif dibanding dengan bahan mekanan lain mengandung $\mathrm{Fe}$. Kadar besi tersecut dapat membantu pembentukan kem dan globin dalam tubuh (Sutomo \& Kurnia, 2016)

Menurut Faralia (2012) bahwa bayam merah banyak mengandung protein, lemak, karbohidrat, kalium, kalsium, mangan, fosfor, zat besi, amarantin, rutin, purin, niasin dan vitamin (A,B1,B2,C), karotin, klorofil dan saponin. Dari hasil pemeriksaan kadar $\mathrm{Hb}$ sesudah perlakuan terbukti bahwa konsumsi ekstrak bayam merah berpengaruh terhadap peningkatan kadar $\mathrm{Hb}$. Observasi peningkatan kadar $\mathrm{Hb}$ yang dilakukan terhadap ibu hamil di klinik vina Medan yang diberi ekstrak bayam merah mendapatkan hasil bahwa 
kadar $\mathrm{Hb}$ ibu hamil di klinik vina Medan tersebut meningkat rata-rata sebesar 0,449 .

Hasil penelitian ini juga sejalan dengan penelitian serupa tentang manfaat bayam merah yang diteliti oleh Ristin Setiyani (201) dengan judul "Manfaat Bayam Merah" diperoleh hasil bahwa bayam merah berguna untuk mengobati penyakit kurang darah. Selain itu ada manfaat lain yaitu meningkatkan kerja organ ginjal, membersihkan darah setelah persalinan, desentri dan memperkuat akar rambut (Syaifuddin, 2015)

Penelitian lain yang sejalan dengan penelitian ini adalah penelitian yang dilakukan oleh Astuti (2015) tentang pengaruh konsumsi jus bayam merah terhadap peningkatan kadar $\mathrm{Hb}$ pada ibu hamil di Kecamatan Tawangmangu diperoleh bahwa nilai kemaknaan $\mathrm{p}<0,05$ artinga ada pengaruh yang signifikan pemberian jus merah sehari sekali selama 2 minggu berturut-turut oada ibu hamil trimester III terhadap peningkatan kadar $\mathrm{Hb}$ (K. H. Astuti \& Widyastuti, 2015)

Menurut asumsi peneliti bahwa kadar hemoglobin pada ibu hamil di klinik vina Medan setelah pemberian ekstrak bayam merah signifikan menaikkan kadar hemoglobin, dapat dilihat ibu hamil di klinik vina Medan ada mengalami penaikan kadar hemoglobin mencapai 93.3\%. Keadaan ini berarti bahwa ada pengaruh pemberian ekstrak bayam merah terhadap kadar HB ibu hamil di klinik Vina Medan.

\section{KESIMPULAN DAN SARAN}

Kesimpulan dalam penelitian ini terdapat Pengaruh antara pemberian ekstrak bayam merah terhadap peningkatan kadar HB ibu hamil di Klinik Vina Medan dengan p-value (0.002).

Adapun saran dalam penelitian ini diperlukan upaya promosi kesehatan, komunikasi informasi dan edukasi (KIE) untuk menambah pengetahuan ibu hamil tentang bayam merah yang dapat meningkatkan kadar HB ibu hamil sehingga dapat menghindari ibu dari resiko kematian pada ibu dan bayi selama kehamilan dan persalinan karena anemia.

\section{DAFTAR PUSTAKA}

Astuti, K. H., \& Widyastuti, A. H. (2015). Pengaruh konsumsi jus bayam merah terhadap peningkatan kadar $\mathrm{Hb}$ pada ibu hamil di Kecamatan Tawangmangu. Bidan Prada: Jurnal Publikasi Kebidanan Akbid YLPP Purwokerto, 6(1).

Astuti, R. Y., \& Ertiana, D. (2018). Anemia dalam Kehamilan. Pustaka 
Abadi.

Dieny, F. F. (2014). Permasalahan gizi pada remaja putri. Yogyakarta: Graha Ilmu, 1(4), 49.

Dinkes Medan. (2019). No Title.

Hidayat, A. (2014). Metode penelitian kebidanan dan teknik analisis data.

Kemenkes, R. I. (2018). Laporan Nasional Riskesdas 2018. Jakarta: Kemenkes RI, 154-166.

Lathifah, N. S., \& Susilawati, S. (2019). Konsumsi Jus Bayam Merah Campur Madu terhadap Peningkatan Kadar Hemoglobin pada Ibu Hamil Trimester III. Jurnal Kesehatan, 10(3), 360-366.

Pradana, D. A., Dwiratna, D. W., \&
Widyarini, S. (2017). Aktivitas Ekstrak Etanolik Bayam Merah (Amaranthus tricolor L.) Terstandar sebagai Upaya Preventif Steatosis: Studi in Vivo. Jurnal Sains Farmasi \& Klinis, 3(2), 120-127.

Sutomo, B., \& Kurnia, D. (2016). 378 Jus \& Ramuan Herbal: Tumpas Penyakit Ringan sampai Berat. Kawan Pustaka.

Syaifuddin, S. (2015). Uji aktivitas antioksidan bayam merah (alternanthera amoena voss.) segar dan rebus dengan metode DPPH. UIN Walisongo. 